\section{TECHNOLOGICAL DRIVE, THE SELF AND THE ETHICAL}

\section{Michael Kelly ${ }^{1}$}

\section{Abstract}

I want in this essay to change the way we approach the promise of technology. In bringing out the philosophical substance packed into the highly critical diagnostic portion of Virilio's work, I focus on Virilio's observations concerning the human psychological relation to technology. I argue that a form of resentment similar to that found in Nietzsche's genealogy of morals provides the motivating factor in the push for continual and increasingly rapid technological innovation: technological drive follows from fallen man's desire to reconcile his mortality. Understanding this drive brings home the direness of the human condition that makes technological promise so attractive and technological resistance so difficult. Given this conundrum, we must articulate an ethic of technological modesty. An ethic of technological modesty encourages (1) the resistance of capricious urges for technological satisfaction and (2) the subjection of technologies to a rigorous phenomenological investigation that weighs their potential benefits and reductions, as well as the conditions that might precipitate and exacerbate these benefits or reductions. This ethical plan

\footnotetext{
'Fordham University, Bronx, New York, USA.
}

pushes Virilio's phenomenology of the "accident" of technology, and comes in the phenomenological/pragmatic tradition of Hans Jonas' imperative of responsibility and Don Ihde's phenomenological investigation of the dimensions of technology that amplify and reduce natural human capacities.

\section{Introduction: Technology and Lived-Experience}

It is difficult, I think, to align oneself in the debate concerning the liberating or coercive aspects of contemporary information technologies. I work in a computer lab to subsidize the finances of my academic life-style, and each day I see young people sitting next to one another in a silence broken only by the clicks resonating from a keyboard. He sends messages from a terminal in Manhattan to a web-pal in Miami, Florida; she messages her cousin staying up late in the Philippines; another writes a friend vacationing in Scotland. Their interaction takes place beyond their lived space and time in a disembodied, virtual realm of global time, and at the sacrifice of a more proximal, physical communication. The lure of "instantaneous" communication across previously unthinkable physical distances and time zones results in a privileging of the far and a devaluation of the near. ${ }^{2}$ Outside of the North Americas and Europe, the fear

\footnotetext{
${ }^{2}$ Cf., Hector Jose Hyuke, "Technology and the Devaluation of the Near," presented at the 12th biennial meeting of the Society for Philosophy and Technology, July 7-9, 2001, Aberdeen, Scotland.
} 
looms that the global-time of American techno-capitalism will increasingly subvert the time of their culture. Non-western countries worry that the global economy that commodifies their collective cultural consciousness will eventually trample their traditions and values, and replace them with the ideals of American techno-capitalist culture that govern our information age. ${ }^{3}$

Yet I do not want to make the hasty claim that all computer-mediated interaction takes place in global time at the expense of the local (both spatial and temporal). Such a claim would be naively one-sided and experientially unverifiable. Indeed, these students sitting side by side will often chat with one another (or another local friend or colleague) via the direct transmissions of instant-messenger. These students share the same physical space. Their interaction, though mediated, takes place within the same temporal and geographical boundaries as interaction that is experientially lived and commonly conceived. Instances of users sharing the same lived-space and -time while favoring technologically mediated, disembodied interaction, bring into question the pessimistic conclusion that technology has triumphed over the lived dimension of experience.

Certainly, more even-headed theories of technology remind us that the aforemen-

\footnotetext{
${ }^{3}$ For an Eastern perspective on this matter, see Soraj Hongladarom's "Time, Nature, Technology and Globalization." Presented at the 12th biennial meeting of the Society for Philosophy and Technology, July 7-9, 2001, Aberdeen, Scotland.
}

tioned criticism of the technological domination of culture, space and time overlooks the liberating capacities that information technologies offer to both western and non-western users. Despite technology's allegedly manipulative aspects, satellite television and the fiberoptic transmissions governing the information superhighway deliver immediate notice of crucial events. For example, I can get information concerning a possible political uprising in Northern Ireland that challenges the local political structure's oppressive policies, or I might receive an email-letter that requests my support for women's rights in Afghanistan or India. These transmissions often awaken us in the west to a more sympathetic, better-informed view of the tribulations or advances of other cultures. More importantly, they make available information that we otherwise might never have known. Such interaction fosters the possibility for new forms of community, a global citizenship, if you will, for through such interactions, one becomes more appreciative of cultural differences, as well as racial or sexual differences within one's local culture and community. Hence, it seems the information age boasts a certain humanism.

The kinds of cross-cultural communication discussed thus far seem promising because, as critical theorist Douglas Kellner argues, they "open ... new public spheres and the possibility of political intervention by groups and individuals excluded from political dialogue during the era of Big Media, controlled by the state and giant corporations." ${ }^{4}$

\footnotetext{
${ }^{4}$ Kellner (2000: 107).
} 
With the information age still at a relevantly inchoate stage of development, Kellner continues, it seems imprudent to risk either a technophobic critique or a technophilic affirmation of the information age. Yet our engagements with technology compel us beyond a neutral stance regarding the promise of technology, and citizens of the modern, global world seem sharply divided in their relation to it: those dismissive of technology and those wildly optimistic about technology.

Regarding these factions debating the promise of technology, I believe that the force of experiential evidence to date concerning information technologies justifies a call for caution. This call for caution might easily be misunderstood as a technophobic appraisal of our information superhighway. Even the above cases illustrating the emancipatory dimensions of information technology, I would argue (but will not in this essay), contain some pernicious private or public interest lurking behind the dissemination of information received by users. Ignoring the more suspicious rhetoric, consider what happens when a user sacrifices the local community, the nuclear family, or the atomic family - that is, the temporally and geographically proximal - to the comforts, satisfactions and caprices of the global. Worse, consider what happens when the techno-capitalist structure imposes itself on a culture and forces its members to sacrifice the local to the global. ${ }^{5}$

${ }^{5}$ Cf., Hongladarom (2001).
Let us take an example dealing with the former hypothetical scenario. Imagine a homosexual male marginalized by the narrow-minded society in which he lives. Now suppose that he not only has kept secret his sexual orientation (as is often how we hear such cases conveyed to us), but also has found a surrogate family on-line. With this family, he feels comfortable to be himself and voice his fears. Perhaps he experiments with tactics for how best to reveal his sexual identity to the members of his community, and receives helpful advice for how to manage their responses. One rightly finds it hard to argue against the benefits of such a cyber-scenario that creates a new community on-line, a community where the marginalized finds a voice, and friends over distances lend an understanding ear, helpful guidance, and reassurance. ${ }^{6}$ The case of our homosexual living out his secret sexual identity in his on-line community seems like an attractive alternative; but it might also entail the following potentially disastrous consequences, according to French culture critique and phenomenologist Paul Virilio:

The paradoxes of [the information age with its new telecommunications equipment] are indeed numerous and disconcerting, in particular the foremost among them: getting closer to the 'distant' takes you proportionally from the 'near' ... the friend, the relative, the neighbor-thus making strangers ... of those who are close at hand ... .?

\footnotetext{
${ }^{6}$ Cf., Turkle (1995: 177-206).

${ }^{7}$ Virilio (1997: 20), my bracketing.
} 
In addition to the dissolution of the proximal community and a sense of acceptance not physically realizable, such recourse to the comforts of an on-line community perpetuates the prejudices and stereotypes of the mind that remains comfortably unchallenged. Only under the strongest utopian conditions, I think, will the liberating forces of the information age prove to facilitate communication and promote a truly democratic community of global citizens.

In this essay, however, I do not want to argue against the potentially democratic and liberating power of information technologies-Kellner makes a valid point that it seems too soon to pass judgment on these tools. I want to argue for a change in the way we passively approach technology with a blind faith in its promise. And to do this we must begin with an inquiry into the origin and perpetuation of our (often times) unreflective optimism.

As citizens of this global information world continually become more amenable to representing themselves over telecommunications mediums such as the internet, no longer does only the object of perception, but also human life itself - the two together comprising concrete, lived-reality-now gets substituted for a virtual one. Concrete reality does not disappear, but undergoes a continual and increasing deprivileging. ${ }^{8}$

The age of classical epistemology centered the subject and initiated the disappearance of the concrete object inso-

${ }^{8}$ Kellner (2000: 110). far as, after Descartes, what was "objective" conformed to the conditions of the subject and the subject's demands for clarity and distinctness. This form of idealism, wherein the cognitive structures of the human mind determined how objects in reality appeared, privileged the human subject as the center of the world. It was but a short step from here to humankind's decentering of itself through technological innovations that privileged the abstract, virtual representation of objects over the experience lived through our natural human capacities. Since modern epistemology's method of inquiry requires that all things receive their being through conformity to consciousness' demands, then when the subject attempts to think itself, it must represent itself as an object present to self-consciousness; the self never appears as "self," it appears only in a "represented" form as an object reflected-on. Given the absence of the self in modern epistemology, it is not surprising that a form of technological idealism replaces the idealism of classical epistemology, for its dematerialized version of the real provides a clarity and distinctness to which the lived-experience pales in comparison.

Technological idealism not only dominates the objects of the world, altering our perception of the world and other human selves, but it also turns back upon itself and usurps its creator. Virilio articulates a reduction of the individual to fractured, immaterial representations that parallels the dissolution of the city, urban-center. When the self too becomes an appearance registered on the web, its concrete reality nestled behind a virtual version, the question of alterity, other- 
ness, ethics and in turn democracy, becomes problematic, for the notion of a community of selves, whose characters we now identify according to the images to which fragmentary and discontinuous links direct us, makes difficult the question of the identity of the self who calls me to ethical responsibility.9 As Virilio writes,

The specific negative aspect of these information superhighways is precisely this loss of orientation regarding altertity (the other), this disturbance in the relationship with the other and ... the world. ${ }^{10}$

I want to claim that liabilities built into technology, such as virtuality's threat to character identification-ultimately a threat to ethics and democracy-are cause enough to issue an imperative to examine with great care the potential benefits and costs of implementing or encouraging the use of new technologies. First, and mainly through an elucidation of the work of Paul Virilio, I suggest that such an investigation must begin with an understanding of humanity's technological drive. In bringing out the philosophical substance packed into the highly critical diagnostic portion of Virilio's work, I focus on Virilio's observations concerning the human psychological relation to technology. I argue that a form of resentment similar to that thought in Nietzsche's On the Genealogy of Morals provides the motivating factor in the push for continual and increasingly rapid technological innovation: technological drive fol-

${ }^{9}$ Cf., Ibid., 102; (see also der Derian, 1998: 2).

${ }^{10}$ Virilio (1995: 4). lows from fallen man's desire to reconcile his mortality.

Understanding this drive opens our eyes to the direness of the human condition that makes technological promise so attractive and technological resistance so difficult. Given this conundrum, we must articulate an ethic of technological modesty. An ethic of technological modesty encourages (1) the resistance of capricious urges for technological satisfaction and (2) the subjection of technologies to a rigorous phenomenological investigation that weighs their potential benefits and reductions, as well as the conditions that might precipitate and exacerbate these benefits or reductions. This ethical plan comes in the phenomenological/pragmatic tradition of Hans Jonas' imperative of responsibility and Don Ihde's phenomenological investigation of the dimensions of technology that amplify and reduce natural human capacities. Virilio shares the sentiments of these latter two thinkers, both that an imperative is needed to quell the technological push and the awareness that since technology can neither be stopped nor turned back we need a method according to which we may evaluate its impact on human life.

\section{Philosophical Influences on Virilio's Philosophy}

Born of Italian descent in Paris, France in 1932, Paul Virilio is an urban planner, philosopher, and military historian and since the early nineteen-seventies has been one of the world's leading critics of industrial and post-industrial 
technology." Through literary and film criticism, military histories and, today, reflections on the telecommunications boom in what he calls the transmission revolution (following the industrial and transportation revolutions), Paul Virilio relentlessly interrogates modern technological culture. Virilio's most original and provocative polemic against the information age concerns the effects of the continuous acceleration of culture. Virilio conceives a new course of study to investigate this phenomenon: dromology. He coins the neologism out of the Latin word dromos meaning a race or running..$^{2}$ Dromology, then, denotes the study of the prevalence of speed in the age of information and the effects of acceleration on the human body, space and time.

Virilio's dromological analysis takes the form of what might be termed something like a common-sense phenomenology, that is, a reading of the effects of acceleration on the things themselves and the spatio-temporal conditions in relation to which all things inescapably exist. To contextualize Virilio's reflections on technology, we must understand that his fundamental observation consists in his belief that the age of instantaneous telepresencing already appears to be corroding the natural order of existence insofar as the temporal receives an uneven privileging over the spatial. Concrete, lived-experience interaction, exhibits two fundamental characters, the 'here' and the 'now.' Thanks to our tele-existence today, however, a new mode of

\footnotetext{
"Cf., Virilio (1998: 1-3).
}

${ }^{12}$ Virilio (1997: 20). interaction that displaces the place of meeting, the 'here,' in favor of its instantaneous character, the 'now,' has become increasingly common-place. ${ }^{13}$ And the totalizing effects of tele-technology do not stop at conquering space; they seek to triumph over time as well. A victim of the technological acceleration of the world, the local time tied to the 'here' becomes homogenized: "that is to say, a worldwide time ... devalues the local time of immediate activity ..." ${ }^{14}$ Having conquered the lived-experience of both space and time, speed produces a virtual experience riddled with paradoxes: concerning space, the far now becomes the near; concerning time, duration is reduced to inertia (as instantaneous transmissions eradicate the time it takes to undertake an activity). As mentioned in the introduction, moreover, these paradoxes of speed entail serious social, ethical and political consequences.

Though always advancing trenchant critiques of the instrumentality of technology, Virilio's writing-style reveals little focus. ${ }^{15}$ Rather than develop a sustained, linear polemic against technology, he speeds through reflection after reflection on technology's impact on human life, piling seemingly disparate observations on top of one another. Given the apparent lack of focus in Virilio's work, some have charged that its frenetic character

\footnotetext{
${ }^{13}$ Ibid., 37.

${ }^{14}$ Ibid., 83.

${ }^{15}$ I do intend to imply that Virilio's body of work lacks focus; Virilio's many books and articles exhibit a consistent polemic that might even be thought repetitive.
} 
reflects rather than corrects the symptoms of the information age with which he takes issue. One such critic, theorist Douglas Kellner, claims that Virilio has a flawed conception of technology that offers no systematic theoretical position and lacks a social analysis that could define a course of political action. In fact, Kellner concludes that Virilio "misses the emancipatory and democratizing aspects of new computer and media technologies."16

Yet in fairness to Virilio, I believe he intentionally avoids articulating a systematic, linear theoretical position. Virilio's aversion to a systematic philosophical discourse follows from his insight that our age is the age of "dromology." Accordingly, Virilio argues that dromological culture eludesor speeds past - any attempt at a systematic analysis; hence his proto-aphoristic writing style offers short, pithy observations and suggestions, sometimes profound, sometimes obscure, but never followed by a linear, systemic discussion. Virilio's disjointed writing style, I would argue further, retains the rhetorical force of decelerating the reader. Virilio encourages his reader to resist the passivity of the dromos and think through the commentary offered. Once the reader makes this effort, it becomes evident that Virilio's work lacks neither a notion of agency nor politics as Kellner charges. Instead, Virilio's reflections on the effects of acceleration on nature and the human species within it contain a subtle and sophisticated awareness of Western philosophy, particularly sym-

${ }^{16}$ Kellner (2000: 103). pathetic to the Christian conception of human nature that technology continues to blur and threatens to erase. Yet, as readers of Virilio can attest, his combination of a sophisticated philosophical stance and a rhetorical style that resists the linear results in a dense text that presupposes equally dense debates concerning technology.

\section{Virilio's Christian Phenom- enology of Technology}

Virilio's thought begins from the conservative line that each human creature has, by design, an inherent dignity and freedom, as well as the capacity for reason, natural selfmovement and moral decision-making. As the speed of our dromological world intensifies-particularly given speed's marriage to economic interest-the compulsion to maintain pace imposes new restrictions on our freedom and renders obsolete the natural capacities of reason from which moral-decision making issues forth. What is worse, remaining on pace with the speed of information becomes possible only after we resign our natural human capacities to the technological prostheses that enable interaction at the rate demanded by the instantaneous transmissions that characterize our dromological age. Virilio's writings seem to imply that technology contains something like a hypothetical imperative: if one wants to maintain pace, then one must conform one's natural faculties to the technologies that enhance 
them. ${ }^{17}$

Virilio warns that such surrender to technology blinds us to the erosion of our natural human capacities. Technological prostheses that facilitate our movement around our environment-from sofa to television, from home to office, from our office in New York to our affiliate office in Tokyo ${ }^{18}$ disable the able and replace the natural design of the human perceptual and cognitive apparatus with faster, more reliable technological versions. The sheer speed of the information age produces an increased reliance on technological surrogates for perception and memory, which, Virilio argues, dull our natural human capacities for rational, moral decision-making. Virilio conclude, then, that "dromospheric pollution is pol-

${ }^{17}$ Babich (1999:112). She writes of the hypothetical imperative of technology: "This is not an ontologically clouded variation on a Luddite theme but a phenomenologically articulated, existentially and pragmatically confirmable commonplace. To use any technological item, even simple machines like a lever or a wedge, the user must conform, i.e., the user must attune him or herself to the tool as such in order to use the tool as suchand not the other way around. This is the hypothetical imperative of technology. If you want to surf the Internet (if you want to ride a motorbike), you must do so within the limits of the Internet including your particular provider/browser (motorbike) you happen to be using."

${ }^{18}$ For Virilio's discussion of these kinds of shifts in human experience, see Virilio (1997:

"Continental Drift"). lution that attacks the liveliness of the subject ..."

As vision technologies continue to replace our natural perceptual capacities and transplant technologies continue to colonize the body, the human species abandons itself to automation and forfeits its natural privileges:

If, according to Kafka, cinema means pulling a uniform over your eyes, television means pulling on a straightjacket, stepping up an eye training regime that leads to eye disease, just as the acoustic intensity of the walkman ends in irreversible lesions in the inner ear. ${ }^{20}$

Virilio seems keenly aware of the consequences that follow from the human being's compulsion to submit to the hypothetical imperative of technology. Technology's hypothetical imperative entails our acceptance of two ineliminable features of technology: (1) that successful engagement with a tool follows from the user's conformity to its guidelines for use, and (2) that the user agrees to the risks - immediate or long-range-involved in its use. Virilio's observation articulates not a one-sided Luddism for the information age. Instead, he highlights what Babette Babich describes as the pragmatically and experientially confirmable fact about technology, whether artefactual or informational, whether a hammer or a web-page. Not only does the speed of

19 Virilio (1997: 33).

${ }^{20}$ Ibid., 97; (see also Kellner, 1998: 8). 
the technology limit our reaction time and/or ability to process information regarding cases that require moral reasoning, but as technologies become increasingly sophisticated, their efficiency requires our increased conformity, thereby decreasing our range of freedom with the tool. The benefits of such interactive equipment come at the sacrifice of the efficacy of our natural human faculties for movement, our freedom to creatively undertake a project, and, as mentioned in the introduction, the threat of the dissolution of the family and political structures.

Virilio's lamentation on the displacement of natural human capacities reveals a phenomenological complement to his theologically motivated critique. Though never addressing his philosophical influences explicitly, MerleauPonty's existential phenomenologywhich Virilio is quite fond of quoting throughout his corpus-fills out Virilio's Christian contention that the human body is endowed with certain natural capacities.

The natural spatio-temporal character of the human body occupies a preeminent place in Merleau-Ponty's existential phenomenology. For him, the body serves as the seat of intentional behavior as humans encounter their environment. What most likely attracts Virilio to Merleau-Ponty's philosophy is the latter's penetrating reflections on the body's relation to instrumental mediation of the world. In particular, the former takes over the latter's insight that when employed in the service of an activity, the technologies we use to navigate the world no longer are perceived [as objects to be analyzed]. Instead, when one becomes comfortable and efficient with a particular technological mediator, the tool in question enters the user's realm of passive habitual activity. As Merleau-Ponty writes, "To get used to a hat, a car, or a stick is to be transplanted in them, or conversely, to incorporate them into the bulk of our own body." 21

Virilio takes very seriously MerleauPonty's phenomenology of the body's relation to tools and technologies, focusing precisely on that which did not immediately concern Merleau-Ponty. While he warns of a techno-colonization of our bodies soon to constitute the "transplant revolution," 22 Virilio finds particularly threatening the imperceptible dimensions of these bodily extensions that continually efface our natural human capacities rather than merely enhance them. Giving particular attention to instances where technology has clandestinely crept into our habit-use, Virilio employs his common-sense phenomenological method to uncover and make clear the loss of the lived-experience of the everyday, whether it be in perception transformed by technologi-

${ }^{21}$ Merleau-Ponty (1962: 153); (see also, Merleau-Ponty 1962: 143 ff.); (Ihde, 1991: $14 \mathrm{ff}$ ). Of course, Merleau-Ponty himself has built this insight upon Heidegger's discussion in Being and Time of practical engagement with the ready-to-hand.

22 "Having nowhere left to go by way of extension, and no time by which to get there in duration, we find suddenly an inversion of the technological trajectory. Reductionism and miniaturization taking over where networking and urbanization left off." Virlio (1997: 49-55). 
cal mediation or the dulling of our motor-skills and bodily motility thanks to interactive prostheses. ${ }^{23}$

We cannot think the Christian element of Virilio's work without thinking his affinity for phenomenology, and vice versa, for, taken together, they comprise his philosophical method for questioning technology. As I read Virilio, his espousal of the Christian view of the human species becomes visible through his phenomenological method, but his Christian faith and respect for the body initially draw him to phenomenology and its ability to assess the extent to which the natural comes to be replaced by either virtual or transplant technologies. His phenomenological reflections on the loss of our god-given capabilities lead him to ask: "[W]hat doth it profit a man if he can gain the whole world but lose his soul? ... Losing one's soul, anima, means losing the very being of movement." ${ }^{24}$ And it is no doubt that Virilio intends the broader meaning of soul entailed in the medieval Christian understanding, where the soul denotes both the source of movement as self-propulsion or local-motion, and also movement in thought, the seat of reason and moral decision-making.

Virilio's theologically informed phenomenological investigations evidence a stronger, more pessimistic inquisition of technology alongside his Christianphenomenology. Clearly, the most sophisticated philosophical roots informing Virilio's critique of technology are found in Heidegger's reflections on in-

${ }^{23}$ Virilio (1991: 111).

${ }^{24}$ Virilio (1997: 25). strumentalism and calculative rationality. ${ }^{25}$ Virilio's affinity for Heidegger's critique of technology comes as no surprise given that Virilio condemns the same mode of enframing thought for transforming natural human capacities that Heidegger earlier declared responsible for the domination of both man and nature.

\section{On Heidegger \& Modern Technology: Ego Cogito and the Ge-Stell}

In Heidegger's reading of the history of western philosophy, the demands of classical epistemology in the modern age precipitate a hegemonic, totalizing technological vision of the world that obliges all nature to conform to human knowledge (i.e., be rendered clear and distinct according to the conditions of the subject), and sacrifices it to the stipulations of human comfort and security. Heidegger reads the German concept of re-presentation (Vor-stellen) back into classical epistemology's claim-spearheaded by Descartes' ego cogito - that perception by a subject reveals an object only if the perception meets the criterion of clarity and distinctness. The German Stellen translates as setting or setting up, and Vor translates as "before": hence, the setting up [of an object] for a subject. Given this modern understanding of perception, Heidegger concludes that Descartes' quest for certainty constitutes nothing more than a question of securing an object under a

${ }^{25}$ Virilio and Lotringer (1983: 28-29). 
subject's clear and distinct perception. ${ }^{26}$

Heidegger calls this mode of perceiving the world the Ge-stell (en-framing), and this enframing presents a prescribed world picture that takes all of nature as standing-reserve, or stock to be used as to meet human demands. The Ge-stell, Heidegger argues, operates with an instrumental form of reason. It is oriented towards only prediction and control that seeks scientific, technological and political domination of the world and its resources. Such a world picture, paradoxically, constitutes an inauthentic vision of the world insofar as the modern subject's re-presentations entail an occlusion of any form of appearance outside the one demanded in the service of human ends and universal calculation. What falls outside the world picture, that is, what cannot be rendered clear and distinct through calculation or technological manipulation, becomes invisible - not in the sense that the back of a house hides itself from one who stands viewing its front, but in the sense that it becomes no-thing, a thing for which we lack a conception. And it is Heidegger's insight into the one-dimensionality of the Ge-stell that Virilio shares with the former and builds upon, for humanity too becomes an object for control. Indeed, Heidegger anticipates Virilio's Christian concerns about the fate of man; he notes that as a consequence of this mode of Ge-stell, man "comes to

${ }^{26}$ Carr (1999: 19-20). Carr provides a concise summary of Heidegger's critique of modern metaphysics and its relation to technology, discussing in greater detail the etymological significance of Vorstellen and Descartes' relation to Hegel, Nietzsche and technological rationality. the point where he himself will have to be taken as standing-reserve." ${ }^{27}$

\section{The Nietzschean Element of Virilio's Thought}

As I read Virilio's work, his diagnosis of our technological world marks a contemporary example of Nietzsche's most daunting prophesies concerning the consequences of the nihilistic attitude Nietzsche termed ressentiment. In general, Virilio repudiates the nihilistic aspects of Nietzsche's anti-Christian writings and in doing so rejects Nietzsche's notion of the will as nihilistic as well. ${ }^{28}$ But this rejection of the Nietzschean notion of will follows from Heidegger's mistaken reading of Nietzsche on the will that Virilio appropriates.

For Nietzsche, as we know, everything is will to power. But if everything is will to power, then surely we must draw distinctions in kinds of wills, for Nietzsche is certainly no reductionist. Nietzsche distinguishes two kinds of will broadly: a will to power that affirms life and a will to power informed by resentment and rancor that rejects life. According to Nietzsche, we find nihilism proper only in the latter mode of the will to power. If I am correct and Virilio's ruminations continue Heidegger's question concerning technology-and Virilio has admitted this much himselfthen clarifying the grounds supporting Heidegger's philosophy of technology should establish Nietzsche's influence on Heidegger's, and thereby Virilio's, critique of technology.

\footnotetext{
${ }^{27}$ Heidegger (1977a: 27).

${ }^{28}$ Armitrage (2000a).
} 


\section{Rethinking Heidegger's "The Word of Nietzsche"}

In his essay "The Word of Nietzsche," Heidegger presents a monolithic reading of the history of western metaphysics, wherein he reduces Nietzsche's notion of the will to the company of Descartes' or Hegel's "commanding" ego cogito, which orders the world into an object of assault. ${ }^{29}$ Contrary to Heidegger's misreading of Nietzsche, the latter's notion of the will desires not a pre-scribed organization that constitutes the world according to its representations. Instead of a form of reason that coerces objects to fit its methods, criteria and cognitive framework, Nietzsche understands will as a force that desires only to affirm and enjoy its own difference: "The pleasure of knowing oneself different ...". ${ }^{30}$ Indeed, Heidegger's sweeping account of the history of modern philosophy egregiously misses Nietzsche's antipathy towards the resentment that riddles Hegel's unhappy consciousness - that is, self-consciousness' reckoning with the Cartesian requirements for clarity and distinction - born out of a desire to have its power recognized. ${ }^{31}$ For the reader familiar with Nietzsche's thought, Heidegger's misreading comes as no surprise, since Heidegger reduces desire and reason to the same constituting ego initiated by Descartes. ${ }^{32} \mathrm{~A}$ closer look at Nietzsche's On the Genealogy of Morals will, I hope, correct Heidegger's misunderstanding.

${ }^{29}$ Heidegger (1977b).

${ }^{30}$ Nietzsche (1989a: section 260).

${ }^{31}$ Deleuze (1993: 8 ff.).

32 Carr (1999: 21).

\section{On Nietzsche's Two Notions of Will: Affirmative and Nihilistic}

The first book of On the Genealogy of Morals explains Hegel's unhappy consciousness under the alias of the priest, and discusses the problem of the idealist's conceptualization of nature as a result of a priestly sleight of hand..$^{33}$ Rather than reckoning with his natural capabilities and place in the world, the oppressed priest lusts after control and recognition, a lust that stems from a deep-seated ressentiment over his lack of power in the social sphere. Despite his political impotence, the resentful man preserves his desire for recognition within the realm of life he finds valuable. Being too weak to secure the ruling power he desires and values, he endeavors to change the conditions demarcating weak and strong, good and evil. Left without physical recourse to attain the power he desires, the priest decides upon articulating an alternative re-presentation of good and evil, thus retarding the natural order of the noble and the plebian, in favor of the abstract order of the good and the evil. ${ }^{34}$

The use of abstract reason, concepts, logic and syllogisms, Nietzsche argues, takes nature's forces, conceptualizes them, and renders them controllable variables in the service of unveiling life's deepest secrets. ${ }^{35}$ Nietzsche terms

33 Nietzsche (1989b. Essay 1, sections 111).

${ }^{34}$ Reginster (1997: 285 ff.).

${ }^{35}$ This is the major polemic defining both Nietzsche's The Birth of Tragedy and his essay "On the Uses and Abuses of History," in Untimely Meditations. Cf., Nietzsche (1997: 62 ff.), and Nietzsche (1956). 
this use of reason to make intelligible and bearable life's concrete dimensions, nihilism. Nietzsche's genealogy further uncovers a corresponding moral phenomenon, asceticism. Asceticism denotes, for Nietzsche, the practice of abandoning the chaotic, often times painful, concrete world of lived-experiences for the orderly, benign world of abstract re-presentations. Ascetic culture bears the psychological marks of its founder's ressentiment, for it arises out of a nihilistic reproach of concrete life.

That the impetus for technological innovation follows from ressentiment might seem a questionable claim. If Nietzsche's On the Genealogy of Morals suggests that the character of resentment evolves from the powerless, does not my suggestion that technological innovation evolves from and perpetuates the spirit of resentment seem inconsistent? To ask the question differently, are not those behind technological innovation and policy-making typically the economically and politically powerful rather than the powerless? This objection rightly notes that the first essay of the Genealogy proclaims that resentment arises from those (particularly Christians) who begrudge the powerful and seek a way to reverse the existing power structure. Indeed, those who today occupy the position of decision making regarding technological innovation may be the powerful. But, if Nietzsche sees correctly humankind's relation to its impotence and the history of social power structures and hierarchies, then we must consider two points when establishing this connection between resentment and technological drive, one historical, the other philo- sophical.

Regarding the former, if the Christian movement has succeeded in reversing the values of good and bad-and Nietzsche thinks it certainly has, for this inversion, he believes, makes human history interesting - then those in positions of power follow in the lineage, genealogically, from the originally resentful "priests." That being said (and here the historical converges with the philosophical), the fundamental technological drive remains nihilistic, a way of life upheld by the kin of the priest. The technological impulse to correct life's hardships and pains preserves the original "Christian" sentiment of resentment. Hence, I suggest that technological innovation, the drive to correct life, is borne out of resentment, the drive to overcome life's transience and mortality. ${ }^{36}$ Indeed, the multinational company's leader - the contemporary clergy - so intent on preserving his illgotten wealth and power, creates an alluring system with promises (much like the priest's promise of life after death) that enslave its followers (the consumers and marginalized).

Heidegger's critique notwithstanding, it should be clear that Nietzsche understands two senses of will: the affirmative and the nihilistic. The former denotes a will that seeks to react to life on life's own temporal, concrete and enig-

${ }^{36} \mathrm{Cf}$., Babich (1994). Babich argues that it is the ascetic dimension of the priest psychology that we see in our contemporary technological drive. I differ from Babich only in emphasizing more the element of resentment. 
matic conditions. The latter denotes a misplaced will to power that seeks to overcome, or reject life's temporal, concrete and enigmatic conditions, a will to power manifested by the psychological condition of ressentiment and perpetuated by its moral counterpart, asceticism. It is the latter form of will, which seeks control over life by conceptualizing nature in an attempt to force it to answer to the subject's demands, that Heidegger narrowly and mistakenly understands as Nietzsche's notion of will. Correctly understood, Nietzsche's notion of will opposes the truly nihilistic, life-degrading motives of reason characteristic of western metaphysics. Insofar as Nietzsche's critique of ressentiment and the ascetic ideal amounts to a critique of idealism's totalizing thought that seeks to secure the object under the demands of a subject seeking answers to life's riddles, his influence on Heidegger - and thereby Virilio - should now be clear.

\section{On the Riddle of Life: Virilio's Relation to Nietzsche}

As Nietzsche understood it, the riddle of life that idealism yearned to correct was the condition of existence marked by transience and an unavoidable mortality. Today, as Virilio understands it, the riddle of life - having been remedied technologically with idealistic forms of perception giving way to virtual representations, etc. - becomes the riddle of technology - and Nietzsche would not disagree, since for both thinkers, "it has always been a matter of clearing the surface of anything in the way," even death itself. ${ }^{37}$

Virilio's disenchantment with contemporary humanity's tendency for abandoning its physical capacities for the sake of technological prostheses smacks of Nietzsche's rejection of the nihilistic ambitions of the religious, scientific and technological variations of resentment. ${ }^{38}$ Indeed, for Virilio, the totalizing effects of speed on space and time, and the paradoxical consequences such technological tyranny entails, evidences the nihilistic flight from life Nietzsche first detected in Socratic reason and later in religion, which science and technology have supplanted. Before the technological boom of the information age, Nietzsche rejected those forms of theoretical idealism-religion, science and classical epistemology - that privileged the abstract or conceptual over life. Today, Virilio voices with equal disdain his challenge to technological idealism, wherein the virtual, the abstract, continually substitutes the real. Indeed, Virilio has written with Nietzschean candor, "what will prevail is this will to reduce the world to a point where we can possess it." ${ }^{39}$ While in interviews Virilio has taken issue with Nietzsche's wont to reduce Christianity to the totalizing modes of science and technology, ${ }^{40}$ both thinkers share in common this fundamental intuition concerning the nihilism of technological idealism.

\footnotetext{
37 Virilio (1997: 81).

38 Babich (1994: 137).

39 Virilio (1998: 11).

${ }^{40}$ Armitrage 2000b: 34).
} 
Virilio's phenomenology pushes Nietzsche's prescient observation that the resentful will behind the ascetic ideal levels, weakens, and infects humanity. Noting that technology socially, psychologically and physiologically exiles humanity from its natural conditions, Virilio concludes that the citizen of the technological world, with everything instantaneously available on the spot, produces the latest version of humanity, the "terminal citizen." Virilio's concept of the terminal citizen puns on the word 'terminal,' and produces images of the over-equipped able-bodied person who, having transferred his "natural capacities for movement and displacement to probes and scanners which instantaneously inform him about a remote reality," now possesses less mobility than the disabled citizen, and is doomed to inertia, to a terminal, or to undermine his very life. ${ }^{41}$

The accident of acceleration and nonlocal activity, i.e., its unintended consequence, is inertia. Confining ourselves to our immediate physical space, having atrophied our natural capacities, Virilio postulates that the terminal citizen precipitates "the sudden mobilization of the illusion of the world ..." 42 Terminal citizen, then, demands and creates the most life-disdaining technology to date, virtual reality, wherein everything occurs in the abstraction that Nietzsche so detested. One good technological turn deserves another and so to "correct" this unsatisfactory, cosmetically perfect reality that we have fabricated, the religion of technology has

\footnotetext{
${ }^{41}$ Virilio (1997: 16).

${ }^{42}$ Ibid., 11.
}

forced the creation of another "dimension" of reality. ${ }^{43}$

\section{Reading a Phenomenological Ethic in Virilio's Critique of Technology}

Virilio takes the notion of the accident quite seriously. Prior to the displacement of local time and local space by today's world of tele-communicative, non-local interaction, accidents occurred in, and their effects were confined to, the local. In our world where interaction occurs in the virtual realm of 'real-time' electronic market trading, accidents now threaten the socio- politico- economic stability of all countries. Technology delocalizes the accident, leading to the threat of a generalized accident (e.g., a stock-market crash or nuclear holocaust). ${ }^{44}$ Perhaps surprisingly, Virilio does not allow his alarm concerning the de-localization of the accident to result in an impulsive, exhaustive disavowal of technology. Instead, he calls for an investigation into the accident:

the question, 'Can we do without
technology?' cannot be asked as
such. We are forced to expand the
question of technology not only to
the substance produced, but also to
the accident produced ... Every
technology, every science should
choose its specific accident, and
reveal it as a product-not in a
moralistic, protectionist way
(safety first), but rather as a prod-

${ }^{43}$ For an interesting discussion of Virilio on tele-presence and the motivation for inventing virtual reality, see I. R. Douglas (1998).

${ }^{44}$ Virilio (1998: 20). 
uct to be 'epistemo-technically' questioned. 45

Citing Heraclitus, Virilio believes we must put out the excess, not the fire. ${ }^{46}$

Virilio's phenomenology of technology maintains that (1) technology cannot be thought of purely as a neutral mediator improving the world with each new innovation, and (2) every technology contains benefits and reduction, improvements and accidents by design, which substantiates his first point in the debate against technological optimists. Virilio maintains that each technological innovation entails a correlative danger: the airplane entails the danger of the plane crash; the television entails the danger of eye damage and the breakdown of familial interaction, etc.

However skewed his diagnosis of the technological age may appear, we must not dismiss as one-sidedly pessimistic Virilio's claim that an accident inheres by design in every technological invention. Instead, Virilio's notion of the accident denotes a pragmatically confirmable account of any invention insofar as that invention necessarily contains unintended uses and consequences. Virilio's relation to technology, then, must be viewed as an ambivalent one, which realizes that a blanket critique of technology will not unlock its riddles.

${ }^{45}$ Virilio and Lotringer (1983: 31-32). We will have to return to this matter of "epistemo-technical" questioning, for it entails the possibility of operating within an instrumental mode of reason much like we found in the Ge-stell.

${ }^{46}$ Virilio (1997: 84).
Indeed, Virilio's concept of the accident resembles a position articulated in the work of American phenomenologist, Don Ihde, who also attempts to straddle the line between technophobic and technophilic appraisals of technology. ${ }^{47}$ Rather than moralistically approach technology and condemn it in advance as a protectionist would, Virilio advocates an epistemo-technical questioning, in other words, a phenomenological investigation.

Hence, abandoning technology is an untenable option, according to Virilio. Even if humanity some day could muster the abundance of strength necessary to give away our technological control, we could not justify the millions who would die as a result of giving up these technological means that now function as the world's life-support system. The tension, not easily resolvable, is an existential and pragmatic one. On the one hand, Virilio understands the need to resist reveling in the infantile pleasures of technology. On the other hand, the pragmatic consequences of a blind resistance to technology seem disastrous.

We already have suggested that the nihilistic character of resentment fuels the fire that renders technology dangerous rather than a purely neutral, purely advantageous entity. And through his reflections on technology and the accident, Virilio exposes this nihilistic drive as that which turns back upon itself and threatens the ruin of all the advantages for which it may take responsibility. Virilio's ethical call in the face of the accident displays similarities to Han

${ }^{47}$ Ihde (1991: $\left.75 \mathrm{ff}\right)$. 
Jonas' imperative of responsibility. ${ }^{48}$

\section{On Virilio's Heuristic of Fear $\&$ a Correlative Phenomeno- logical Ethic}

Hans Jonas contends that our powers for technological manufacturing and innovating have outstripped our powers of prediction, precluding the possibility of knowing with certainty the long-range effects of our new technologies. Our resentful desire for incessant technological advance ironically presents an unknown in the face of which we must exhibit a new humility, or caution. Jonas suggests, then, that we must exercise a "heuristics of fear" to temper our excessive ability to create and act through technological means, the consequences of which can be known only in retrospect. Whereas Jonas and Virilio seemingly espouse a similar heuristic of fear, the tenets of Jonas' own theory render it ethically paralyzed, for Jonas rules out from the start the possibility of knowing long-range effects of technological applications. Virilio's reflections on the accident, I suggest, employ something

\footnotetext{
${ }^{48}$ For a discussion of Jonas not specifically couched in the language of resentment as we have adopted it here, see Mitcham (1994: 104-105). Mitcham also draws a fine parallel between Jonas' secular, deontological ethic and Ellul's theological ethic of nonpower. I choose Jonas here over Ellul (despite the obvious theological connection between the latter and Virilio) because Virilio, as I read him, would be more sympathetic to Jonas' ethic that seems to advocate a use of technology, but a humble one, rather than solely a resistance, which Ellul sometimes appears to espouse.
}

like Jonas' ethical thought as a propaedeutic, and could augment the latter's insight by offering a phenomenologically substantial model of inquiry by means of which we may apply this heuristic of fear.

What I am calling Virilio's ethic of technology couples the phenomenological conclusion for the inevitability of the accident with a heuristic of fear to prophesize a potentially severe generalized accident in the hope of promoting a modest, more ethically sensitive use of technologies. Unlike Jonas' ethically paralyzed vision, Virilio does not believe that the impossibility of making "certain" predictions concerning technology's consequences need entail the impossibility for postulating reasonably foreseeable assessments of a technology's impact. Virilio's phenomenological method allows him the opportunity to weigh with more than less accuracy the benefits and reductions of any technologically mediated situation in lived-experience- on either the global or local level.

Taking an example that Ihde uses well, the telephone presents the benefit of communication over a distance, and amplifies the distance over which we might interact with another. At the same time, however, the telephone eliminates the face-to-face interaction of lived space and reduces the human participants to a voice. With Virilio, we might take this further and phenomenologically evaluate the students in my computer lab. The distance over which they communicate via instant-messenger remains the same, but the benefits now are a faster connection and a form of com- 
munication more affordable than telephoning, which in turn offers the possibility of prolonged interaction. At the same time, however, instant-messenger further disembodies the human participants, stripping them of even their voice, and further reduces them, condemning them to self-presentation through a uniform type-script that will deliver their messages. Gone is the emphasis and affection brought by tonal inflection. In its place we find emoticons, type-scripts symbolizing anything from smiles to frowns, winks to tears. ${ }^{49}$ Taking our phenomenological investigations further again, this time to a social level, these communication mediums bring the far to presence, but at the expense of rendering distant the near.

Let us recall our case of the homosexual who finds solace in an on-line community and apply this phenomenological ethic of modesty. The obvious benefits - comfort, an efficacious space for the marginalized, psychological wellbeing, desensitization into the community - extend only to personal interests within a private realm, with peripheral public interest. The obvious reductions - further fracturing of familial and communal intimacy, false sense of security, users in bad faith possibly manipulating private information, and, perhaps undermining the efforts for establishing an on-line community, hierarchies forming within the on-line community itself-impact precisely in the public realm insofar as the on-line community serves only as a flight from reality and responsibility.

Challenging the notion that an on-line community entails certain social regres- sions, one might suggest that one reasonably can foresee the process of desensitization precipitating a very public, non-virtual movement for gay rights in this prejudiced community. Once comfortable in a virtual realm, a leader may emerge as the catalyst of social change, bringing with him or her the lessons learned in an arena where his or her voice was left uninhibited by social dictates. Such a political advance would evidence, no doubt, the potentially liberating forces of the internet. One might object that the liberal's presumption that a leader will emerge, or the psychologist's hypothesis that desensitization will transfer from the virtualsociety to the natural-society, amounts only to speculation. Yet such skepticism cannot justify harnessing the potential powers of this medium to save the proximal social structures of family and society, which presumably require rethinking, since they initially triggered the user's flight from reality and society. It appears that we must evaluate each instance individually, taking into account the myriad of variables that make its situation unique.

But one presumption permeates all hopes for a democratic advance through on-line communities and tele-interaction: the realization of the emancipatory capacity of new technologies requires a limited restriction from the public, nonvirtual voice of normativity, i.e., they must be freed from the powers that originally limited the voice of the marginalized. A paradox emerges, however, for when on-line communities loosen the hold of normative values, this potentially creates a space for anarchistic and tyrannical users within this "free" 
realm, which threatens to stifle the growth necessary to turn virtual realizations into naturally, socially realized events. The precondition for emancipation and democratic advance, then, seems to require the purest form of democracy, which, however, could undermine itself. Hence, our brief phenomenological exercise suggests that it appears (and the short history of the internet confirms that it is) valuable to implement some form of structure in order to maximize the information age's liberating capacities, sacrificing neither the self nor the ethical/social. From this point, the ethicist should join forces with the group attempting to organize and select a mediator, or some other appropriate course of action.

After our brief experimental example of how a community might employ this phenomenological ethic of technological modesty, one might object further that the very method of a phenomenological ethics of technology undermines itself insofar as it operates from the same method of calculative, evaluative reason characterized by the Ge-stell and criticized by Heidegger and Virilio as instrumental. On the surface of it, this objection appears substantial, but everything remains in the details as unpacked through the course of this essay, and the Nietzschean element in Virilio now assumes a crucial role in what we propose Virilio's ethics of technology might look like.

${ }^{49}$ An emoticon might look like this: smile :) or frown : (.
Although philosophers of technology have labeled Heidegger a technological pessimist offering a wholesale critique of rationality, we challenge this critique and understand Heidegger's polemic against technology following from Nietzsche, and alter it accordingly. The dismissal of rationality is not of rationality broadly conceived, but of a certain kind of rationality, instrumental rationality. Rationality in the pejorative sense susceptible to the critique of technology cannot be equated with rationality considered broadly, which examines and seeks to make reasonable suggestions concerning a benefit or reduction of technology. While calculative rationality has received the most criticism among theorists concerned with technology, we must not let drop from our mind that rationality as calculative becomes pernicious only to the extent that it serves technological man's resentful desire to 'correct' life. Neither Nietzsche (the neo-Kantian perspectivalist), nor Heidegger (the existential phenomenologist), nor Virilio (the Christian phenomenologist of technology) wishes to throw away reason; they only wish to throw away the totalizing model of reason in the service of what Nietzsche first identified as nihilistic resentment. The notions of the accident and the heuristic of fear challenge this resentful form of reason that deploys technology unreflectively and excessively, bringing it to its pragmatic extreme where the drive for progress ends in inertia or other forms of termination. The heuristic of fear nevertheless remains an empty theory unless given some phenomenological substance, as Virilio's work seems to do. And more than just offering precautionary flags 
notifying users of potential proximal and long-range consequences, our phenomenological investigation also can alert us to the possibly emancipatory and democratizing potential of a new technology. ${ }^{50}$

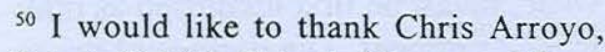
Babette Babich, Roberta Chavez and Soraj Hongladarom all of whom offered helpful criticisms of this paper's early versions. I also would like to acknowledge the invaluable help of Anne Ozar, who offered supportive encouragement, as well as grammatical, stylistic and theoretical suggestions to the text. Finally, I am indebted to Professor Hongladarom for having encouraged me to submit this essay. Of course, all inaccuracies remain my responsibility, despite the best efforts of those above.

\section{References}

Armitrage, J. 2000a. "Beyond Postmodernism? Part 2: Paul Virilio's Hypermodern Cultural Theory." Ctheory, 23, 3 .

-. 2000b. "From Modernism to Hypermodernism and Beyond: An Interview with Paul Virilio." In Paul Virilio: From Modernism to Hypermodernism and Beyond. London: Sage.

Babich, B. 1994. Nietzsche's Philosophy of Science: Reflecting Science on the Ground of Art and Life. Albany, NY: SUNY Press.

—. 1999. "The Essence of Questioning After Technology: Techne as Constraint and Saving Power." British Journal of Phenomenology, 30, 1: 106-124.

Carr, D. 1999. The Paradox of Subjectivity: The Self in the Transcendental Tradition. New York, NY: Oxford Press.

der Derian, J. 1998. "Introduction." In The Virilio Reader, ed, J. der Derian, 1-15. London: Blackwell Publishers.

Douglas, I. R. 1998. "The New Seclusion." http://www.powerfoundation.org/essays/index.html.

Heidegger, M. 1977a. "The Question Concerning Technology." In The Question Concerning Technology and Other Essays. Trans, W. Lovitt. New York, NY: Harper \& Row.

—.1977b. "The Word of Nietzsche." In The Question Concerning Technology and Other Essays. Trans, W. Lovitt. New York, NY: Harper \& Row. 
Hongladarom, S. 2001. "Time, Nature, Technology and Globalization." Presented at the $12^{\text {th }}$ biennial meeting of the Society for Philosophy and Technology, July 7-9, 2001, Aberdeen, Scotland.

Hyuke, H. J. 2001. "Technology and the Devaluation of the Near." Presented at the $12^{\text {th }}$ biennial meeting of the Society for Philosophy and Technology, July 79, 2001, Aberdeen, Scotland.

Ihde, D. 1991. Technology and the Lifeworld. Bloomington, IN: University of Indiana Press.

Kellner, D. 1998. "Virilio on Vision Machines." http://mailbase.ac.uk/lists/filmphilosophy/files/kellner.html.

-. 2000. "Virilio, War and Technology: Some Critical Reflections," 103-126. In Paul Virilio: From Modernism to Hypermodernism and Beyond, ed. J. Armitrage. London: Sage Publications.

Merleau-Ponty, M. 1962. Phenomenology of Perception. Trans., C. Smith. New York, NY: Routledge.

Mitcham, C. 1994. Thinking Through Technology: The Path Between Engineering and Philosophy. Chicago, IL: University of Chicago Press.

Nietzsche, F. 1956. The Birth of T ragedy and The Genealogy of Morals. Trans, F. Golffing. New York, NY: Doubleday.

-.1989a. Beyond Good and Evil. Trans, W. Kaufman. New York, NY: Vintage Books.

- 1989b. On the Genealogy of Morals. Trans, W. Kaufman. New York, NY: Vintage Books.
-. 1997. Untimely Meditations. Trans, R. J. Hollingdale. New York, NY: Cambridge University Press.

Reginster, B.. 1997. "Nietzsche on Ressentiment and Valuation". Philosophy and Phenomenological Research, Vol. LVII, No. 2, June: 281-305.

Turkle, S. 1995. Life on the Screen. New York, NY: Simon and Schuster.

Virilio, P. 1991. The Lost Dimension. Trans, J. Rose. New York, NY: Semiotext(e).

-. 1995. "Speed and Information: Cyberspace Alarm." Ctheory, 27, September.

-. 1997. Open Sky. Trans, J. Rose. New York, NY: Verso.

-1998. The Virilio Reader, e d. J. der Derian. London: Blackwell Press.

Virilio, P. and S. Lotringer. 1983. Pure War. New York, NY: Semiotext(e). 